\title{
THE SNAKES COLLECTION FROM PAPUA, INDONESIA WITH NOTES ON ANALYSIS OF STOMACH CONTENT
}

\author{
Keliopas Krey*1, Denisa Taran ${ }^{1}$, Hendrik Burwos², Irvan Sidik ${ }^{3}$ \\ ${ }^{1}$ Department of Biology, Faculty of Mathematics and Natural Sciences, University of Papua, Amban \\ Campus, Manokwari 98314, Indonesia \\ ${ }^{2}$ Environment Research Center, University of Papua, Manokwari 98314, Indonesia \\ ${ }^{3}$ Laboratory of Herpetology, Zoology Division, Research Center for Biology, Indonesian Institute of \\ Sciences (LIPI), Cibinong, Indonesia
}

*Correspondence: keliopaskrey@ymail.com

\begin{abstract}
A complete list of snake species found in Papua is essential for the conservation and management of these species in the future. This study provides a basic overview of the snake's specimens deposited in the Laboratorium Zoology UNIPA (LZU) at Manokwari, West Papua Province during at last 15 years. In addition, these data are compared with specimens from the Muzeum Zoologicum Bogoriense (MZB) at Cibinong, West Java. We recorded 30 species of snakes from LZU (36.1\%), and 43 species from MZB (51.8\%), of the 83 species reported by Allison (2007). Clearly much more collecting effort needs to be focused on Papua, as less than $50 \%$ of the known species have voucher specimens in a museum. Of the species on collection, Morelia viridis is the only protected species on Papua, while Lycodon aulicus is the only alien species. We also conducted a through investigation of prey content for each species using preserved stomach contents. We dissected a total of 93 specimens. Twenty-nine percent of the specimens contained prey items. We discovered four categories of prey items, whole body, body parts, shell, and hair. The prey items belonged to the following four classes of animals: Reptiles (56\%), Amphibians (16\%), Mammals (19\%), and Osteichtyes (9\%).
\end{abstract}

\begin{abstract}
ABSTRAK
Daftar spesies ular yang ditemukan di Papua sangat penting untuk konservasi dan pengelolaan pada masa depan. Penelitian ini bertujuan untuk menyediakan informasi dasar terkini tentang koleksi ular yang tersimpan di Laboratorium Zoologi UNIPA (LZU) di Manokwari selama 15 tahun terakhir. Selain itu, seluruh data-data ini diperbandingkan dengan koleksi spesimen Muzeum Zoologicum Bogoriense (MZB) Cibinong, Jawa Barat. Seluruhnya tercatat ular sebanyak 30 spesies asal LZU (36.1\%), dan 43 spesies asal MZB (51.8\%), dari 83 spesies yang dilaporkan oleh Allison (2007). Upaya pengumpulan lebih banyak jelas perlu difokuskan di Papua, karena kurang dari 50\% spesies yang diketahui merupakan spesimen pemberian pada museum. Dari keseluruhan koleksi ular, Morelia viridis satu-satunya spesies lindungan asal Papua, sedangkan satu-satunya spesies asing yaitu Lycodon aulicus. Kami juga melakukan penelitian melalui isi mangsa terhadap setiap spesies menggunakan isi lambung yang diawetkan. Seluruhnya item mangsa adalah hewan terdiri dari: Reptil (56\%), Amfibi (16\%), Mamalia (19\%), dan Ikan bertulang keras (9\%).
\end{abstract}

Keywords: Specimens, Prey, Muzeum, New Guinea, Papua

\section{INTRODUCTION}

New Guinea is the second large island in the world after the Greenland, and Papua is the first largest island in Indonesia, encompassing $416.129 \mathrm{~km}^{2}$. Papua is the western half of the mainland island of New Guinea, while the other

half in the east is Papua New Guinea which form as vast landmasses with teresterials ecosystems, as well as an array of endemic species (Beehler, 2007). The habitat mostly consists of tropical rainforest, providing ample opportunity for a 
diverse set of species to flourish.

Papuan snakes are widespread across the mainland as well as small of satellite islands (Waigeo, Batanta, Misool, Biak, and Numfor). Eighty-three species of snakes have been recorded on Papua (Allison 2007), consisting of three percent of the worlds 2700 species (Taylor \& O'Shea, 2004). These eighty-three species are classified into seven families, including Acrochordidae (file snakes), Boidae (boids), Colubridae (tree snakes, water snakes and ground snakes), Cylindrophiidae (asian pipe snakes), Elapidae (front-fanged snakes), Pythonidae (pythons), and Typhlopidae (burrowing snakes). Within these families, Cylindrophis aruensis (Cylindrophiidae,) is an endemic species from the Aru Islands (McDowell, 1975; O'Shea, 1996; Allison, 2007). Five of the seven families except Boidae and Cylindrophiidae were represented in Australia whereas six families except Boidae occured in Southeast Asia. Most families appear to have had a long history in the Indo-Australian region (Allison, 2007).

Snakes have an important role in nature, especially in the food chain. In Java, for example, snakes function as predators for controlling rat pests that often attack rice plants. Even so, humans tend not to like snakes so the role of these animals is not as big as they should be (Whitten et al., 1999). However, so far there has been no information about predatory snakes in Papua. Some reports indicated that a group of elapid snakes may be the main predators of other snake species in New Guinea (Shine \& Keogh 1996; O'Shea 1994a), even more than that, they are cannibals (O'Shea 1994b; Krey et al., 2015). Snakes in Papua New Guinea region prey on lizards, snakes, frogs, insects, small mammals and other prey (O'Shea, 1996; O'Shea, 1994a; Krey et al., 2015), but there is no data on Papuan snakes diet exept Micropechis ikaheka predating amphibians, fish, reptiles, and mammals (Krey et al., 2015).

The snake specimens at LZU provide a series of data to study their eating habits and food preferences. The study also carried out quantitative analysis of food preferences in species, and recorded the number of species that had been stored at the LZU and MZB.

Measuring biodiversity is one of the first steps toward better conservation practices (Knight et al., 2008). Here we present number of Papuan snakes at Laboratorium Zoology UNIPA (LZU) in Manokwari, West Papua, and the Museum Zoologicum Bogoriense (MZB) in Cibinong, West Java. We also present the results of examining the stomach contents of all snakes in the LZU collection.

\section{MATERIALS AND METHOD}

\section{Specimen Collection}

Field trips have been conducted regularly between the years of 2002 and 2016. Collection has been made at all habitat types present, and at elevations up to $2.500 \mathrm{~m}$ ASL. Snakes were captured by snake hook or hand and preserved using $10 \%$ formalin, then stored in $70 \%$ ethanol. All Papuan snake specimens were stored in the Laboratory Zoological UNIPA (LZU) in Manokwari, West Papua. In addition, data were also obtained from the collection of the Zoology Bogorienze Muzeum (MZB) in Cibinong, West Java.

\section{Diet Analysis}

We dissected a total of 93 snake's specimen of LZU collection. We opened the whole abdomen to ensure the retreival of all prey items. We record the location of the prey item (stomach, intestine), and the number and condition of prey items. Due to process of digestion and degredation, we were not able to identify many of the prey item except to Class. Categorization and identification of prey taxa was based on Menzies (1975) for frogs, Brown (1991) for lizards, Rooij (1917) and O'Shea (1996) for snakes, Kimura and Matsuura (2003), and Allen (2000) for Osteichtyes, Menzies and Dennis (1979) for mammals.

\section{RESULTS}

\section{The Species and Specimen Collection of Snake}

Established 15 years ago for the sake of education and research, the University of Papua (UNIPA) continues to make improvements and developments in various fields (Tabel 1 and Figure 1). These data of snake diversity counts from various collecting trips within Papua beneficial to support the study of biology, ecology, evolution and natural history. 
Table 1. Data collection of snakes at LZU and MZB. Note: 1- Manokwari; 2- Bintuni; 3- Raja Ampat; 4- Yapen Island; 5- Waropen; 6- Biak Numfor Island; 7- Jayapura; 8- Mimika; 9-Jayawijaya; 10- Merauke; 11- Fakfak; 12-Mamberamo; 13-Tambrauw, 14-Kaimana

\begin{tabular}{|c|c|c|c|c|c|c|c|c|c|c|c|c|c|c|c|c|}
\hline \multirow[t]{2}{*}{ Famili \& Species } & \multicolumn{2}{|c|}{$\begin{array}{l}\text { Number of } \\
\text { collection }\end{array}$} & \multicolumn{14}{|c|}{ The Origin of LZU Specimen } \\
\hline & LZU & MZB & 1 & 2 & 3 & 4 & 5 & 6 & 7 & 8 & 9 & 10 & 11 & 12 & 13 & 14 \\
\hline$a$ & $b$ & $c$ & $d$ & $e$ & $f$ & $g$ & $h$ & $i$ & $j$ & $k$ & $l$ & $m$ & $n$ & $o$ & $p$ & $q$ \\
\hline \multicolumn{17}{|l|}{ Acrochordidae } \\
\hline Acrochordus arafurae & 2 & 2 & & & & & & & & & & & & & & 2 \\
\hline \multicolumn{17}{|l|}{ Boidae } \\
\hline Candoia aspera & 1 & 17 & & & & & & & 1 & & & & & & & \\
\hline Candoia carinata & 1 & 13 & & & & & & & 1 & & & & & & & \\
\hline \multicolumn{17}{|l|}{ Colubridae } \\
\hline Boiga irregularis & 10 & 30 & 8 & & & & & 1 & & & & 1 & & & & 1 \\
\hline Cerberus rynchops & 0 & 1 & & & & & & & & & & & & & & \\
\hline Dendrelaphis calligaster & 6 & 25 & 3 & & & & & & 1 & 1 & & 1 & & & & \\
\hline Dendrelaphis punctulatus & 1 & 5 & & & & & & & & & & 1 & & & & \\
\hline Dendrelaphis formosus & 0 & 2 & & & & & & & & & & & & & & \\
\hline Pseudoferania polylepis & 0 & 1 & & & & & & & & & & & & & & \\
\hline Fordonia leucobalia & 0 & 1 & & & & & & & & & & & & & & \\
\hline Lycodon aulicus & 1 & 0 & & & & & & & 1 & & & & & & & \\
\hline Stegonotus cucullatus & 11 & 5 & 4 & 1 & 1 & & 2 & 2 & 1 & & & & & & & \\
\hline Stegonotus diehli & 4 & 4 & & & & & & 1 & & 2 & & 1 & & & & \\
\hline Stegonotus modestus & 2 & 2 & & & & & & 1 & 1 & & & & & & & \\
\hline Stegonotus parvus & 0 & 7 & & & & & & & & & & & & & & \\
\hline Stegonotus sp. 1 & 1 & 0 & & & & & & & & & & 1 & & & & \\
\hline Stegonotus sp. 2 & 1 & 0 & & & & & & 1 & & & & & & & & \\
\hline Tropidonophis doriae & 3 & 2 & & & & & & & & & 1 & & 1 & 1 & & \\
\hline Tropidonophis elongatus & 0 & 2 & & & & & & & & & & & & & & \\
\hline Tropidonophis mairii & 3 & 5 & 1 & 1 & & & & & & & & 1 & & & & \\
\hline $\begin{array}{l}\text { Tropidonophis } \\
\text { multiscutellatus }\end{array}$ & 3 & 5 & & 1 & & & & & & 1 & 1 & & & & & \\
\hline Tropidonophis statisticus & 3 & 1 & & & & & & & 2 & & 1 & & & & & \\
\hline Tropidonophis mcdowelli & 1 & 0 & & & & & & 1 & & & & & & & & \\
\hline Tropidonophis picturatus & 1 & 6 & 1 & & & & & & & & & & & & & \\
\hline \multicolumn{17}{|l|}{ Elapidae } \\
\hline \multicolumn{17}{|l|}{ - Elapinae } \\
\hline Acanthophis praelongus & 2 & 17 & & & & & & 1 & & & & 1 & & & & \\
\hline Acanthophis antarcticus & 1 & 0 & 1 & & & & & & & & & & & & & \\
\hline Aspidomorphus schlegelii & 3 & 3 & 2 & & & & & 1 & & & & & & & & \\
\hline Aspidomorphus muelleri & 2 & 13 & 2 & & & & & & & & & & & & & \\
\hline Demansia vestigiata & 0 & 6 & & & & & & & & & & & & & & \\
\hline Furina tristis & 2 & 0 & & & & & & & & & & & & & & \\
\hline Micropechis ikaheka & 14 & 17 & 2 & 2 & 4 & 1 & 1 & & 1 & & & & & & 2 & 1 \\
\hline Pseudechis australis & 0 & 2 & & & & & & & & & & & & & & \\
\hline Pseudechis papuanus & 0 & 2 & & & & & & & & & & & & & & \\
\hline Toxicocalamus loriae & 0 & 1 & & & & & & & & & & & & & & \\
\hline $\begin{array}{l}\text { Toxicocalamus preussi } \\
\text { preussi }\end{array}$ & 1 & 8 & & & & & & 1 & & & & & & & & \\
\hline $\begin{array}{l}\text { Toxicocalamus stanleyanus } \\
\text { - Laticaudinae }\end{array}$ & 0 & 2 & & & & & & & & & & & & & & \\
\hline Laticauda colubrine & 2 & 4 & 2 & & & & & & & & & & & & & \\
\hline Laticauda laticaudata & 0 & 1 & & & & & & & & & & & & & & \\
\hline Aipysurus laevis & 0 & 1 & & & & & & & & & & & & & & \\
\hline Pelamis platurus & 0 & 1 & & & & & & & & & & & & & & \\
\hline \multicolumn{17}{|l|}{ Pythonidae } \\
\hline Liasis papuanus & 1 & 0 & & & & & 1 & & & & & & & & & \\
\hline Morelia viridis & 3 & 6 & 3 & & & & & & & & & & & & & \\
\hline Bothrochilus albertisii & 8 & 6 & 7 & & & & & & 1 & & & & & & & \\
\hline Simalia amethistina & 0 & 6 & & & & & & & & & & & & & & \\
\hline Simalia boeleni & 0 & 1 & & & & & & & & & & & & & & \\
\hline Morelia spilota harrisoni & 0 & 2 & & & & & & & & & & & & & & \\
\hline Liasis fuscus & 0 & 1 & & & & & & & & & & & & & & \\
\hline \multicolumn{17}{|l|}{ Typhlopidae } \\
\hline Indotyphlops braminus & 1 & 2 & & & & & & & & & & 1 & & & & \\
\hline Total of species: & 30 & 41 & 12 & 4 & 2 & 1 & 3 & 9 & 9 & 3 & 3 & 9 & 1 & 1 & 1 & 3 \\
\hline Total of specimen: & 97 & 238 & 36 & 6 & 5 & 1 & 4 & 10 & 10 & 4 & 3 & 10 & 1 & 1 & 2 & 4 \\
\hline
\end{tabular}




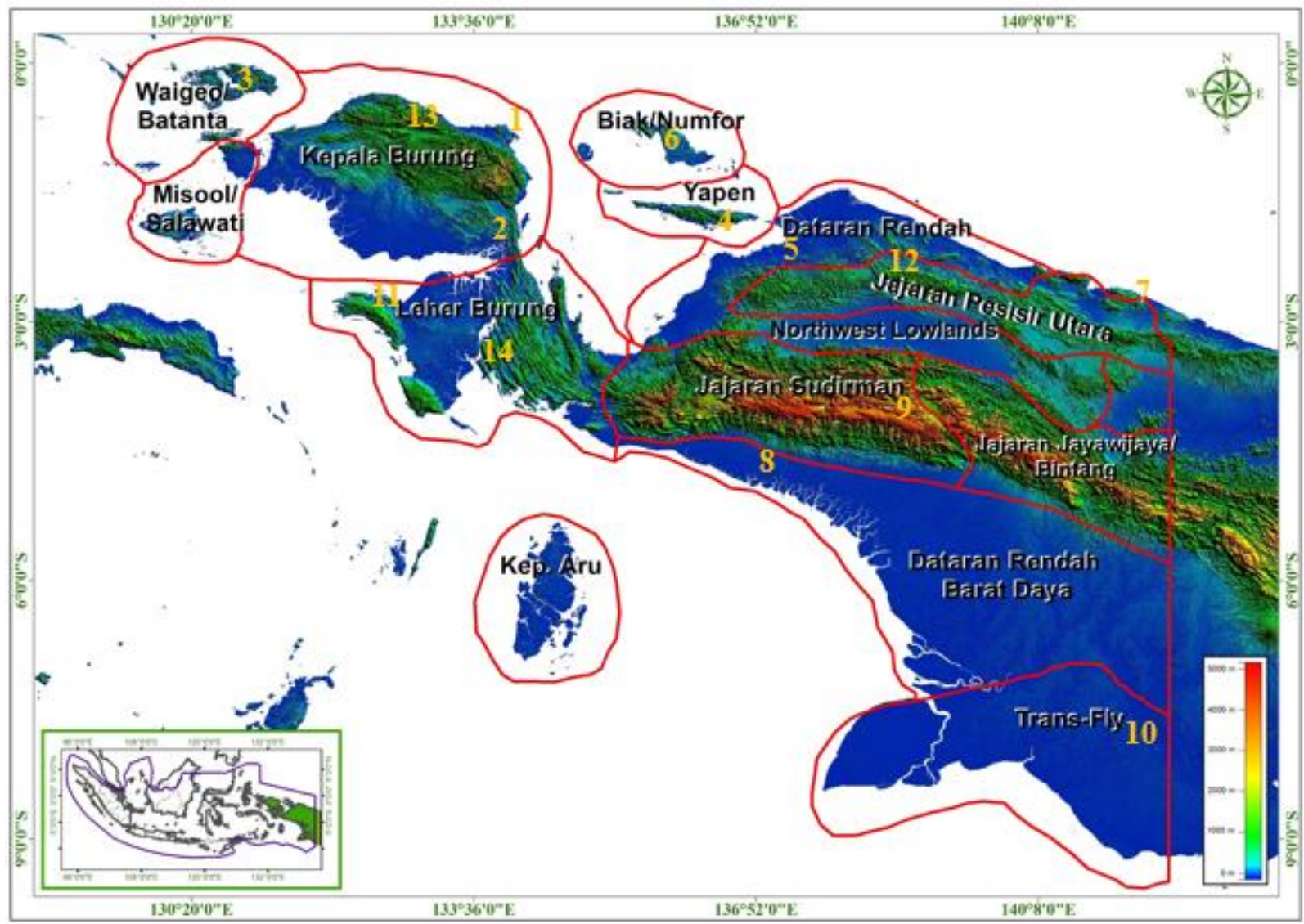

Figure 1. Zoogeographical distribution of snakes in Papua based on LZU specimens

A total of 97 specimens of snakes from Papua were stored in LZU, including 30 species from six families. Though a positive start in understanding Papuan snakes, this collection is still much smaller than that of MZB. Of the 5.451 snakes in the MZB collection, 259 are from Papua, consisting of 43 species from six families (Table 1). The LZU collection originates from a variety of places in mainland of Papua such as Manokwari, Jayapura, Merauke, Bintuni, Mimika, Jayawijaya, Waropen, Mamberamo, Fakfak, Kaimana and some satelites islands like Biak, Numfor, Waigeo, Batanta, and Yapen. Snake species in Papua that have been recorded include species of snakes that live on land, in freshwater and marine areas. Some species have even been recorded from Papua, but have not been found in Papua New Guinea (O'Shea, 1996).

\section{Snake Diet}

While a total of 93 snake specimens from LZU were dissected, only 27 (29.03\%) specimens contained prey items (Table 2). There were at least four categories of prey items, namely whole body, body parts, shells, and hair. Our data show that there are 32 types of prey, which are grouped into four classes: Reptiles, Amphibians, Mammals, and true bony fish or Osteichthyes. Reptiles may be the most important selected prey type with total $56 \%$ (Figure 2). It is assume that many terrestrials snakes in Papua preys primarily on scincid lizards, snakes as well as the eggs of reptiles. Reptiles, especially lizard very abundance and availability in the ground habitats inhabited by snake (Krey obs.) and they may be easier to captured than any other terrestrial vertebrate. The presence of hair or scales represented for mammals or reptiles, hard shells for reptile eggs (Figure 3), parts of the scales and limbs for lizards, and body parts for fish. 
Table 2. Prey items found in the digestive tract of snake specimens in LZU. N: number of specimens

\begin{tabular}{|c|c|c|c|c|}
\hline Snakes Species & $\mathrm{N}$ & Prey Type & Prey Item & Number \\
\hline \multirow[t]{6}{*}{ Acanthophis antarcticus } & 1 & Reptilia & & \\
\hline & & Scincidae & Part of body & 4 \\
\hline & & Sphenomorphus sp. & Whole body & 1 \\
\hline & & Amphibia & & \\
\hline & & Microhylidae & & \\
\hline & & Xenorhina sp. & Part of body & 1 \\
\hline \multirow[t]{2}{*}{ Acanthophis praelongus } & 1 & Reptilia & & \\
\hline & & Scincidae & Part of body & 1 \\
\hline Boiga irregularis & 1 & Pogonomys group & Part of body & 1 \\
\hline Dendrelaphis punctulatus & 1 & Scincidae & Part of body & 1 \\
\hline Dendrelaphis calligaster & 1 & Hemidactylus frenatus & Part of body & 1 \\
\hline \multirow{2}{*}{ Furina tristis } & 1 & Scincidae & Part of body & 1 \\
\hline & & Pisces & & \\
\hline \multirow[t]{3}{*}{ Laticauda colubrina } & 2 & Muraenidae & Part of body & 1 \\
\hline & & Gymnothorax sp. & Part of body & 1 \\
\hline & & Mammals & & \\
\hline \multirow[t]{2}{*}{ Bothrochilus albertisii } & 2 & Melomys sp. & Part of body & 1 \\
\hline & & Pogonomys group & Part of body & 1 \\
\hline Morelia viridis & 1 & Mammals & Hair & 1 \\
\hline \multirow[t]{9}{*}{ Micropechis ikaheca } & 7 & Reptilia & & \\
\hline & & Sauria & & \\
\hline & & Scincidae & Part of body & 2 \\
\hline & & Sphenomorphus simus & Whole body & 1 \\
\hline & & S. mиelleri & Whole body & 1 \\
\hline & & Eugongylus rufescens & Part of body & 1 \\
\hline & & Serpentes & & \\
\hline & & Dendrelaphis sp. & Part of body & 1 \\
\hline & & Mammalia & Hair & 2 \\
\hline Stegonotus cucullatus & 2 & Reptilia (eggs) & Shells & 2 \\
\hline Stegonotus diehli & 1 & Reptilia (eggs) & Shells & 3 \\
\hline Stegonotus sp. & 1 & Reptilia (eggs) & Shells & 3 \\
\hline \multirow[t]{3}{*}{ Tropidonophis doriae } & 1 & Amphibia & & \\
\hline & & Hylidae & & \\
\hline & & Litoria infrafrenata & Part of body & 1 \\
\hline \multirow{5}{*}{ Tropidonophis mairii } & 2 & Pisces & & \\
\hline & & Clariidae & & \\
\hline & & Clarias bathracus & Whole body & 4 \\
\hline & & Amphibia & & \\
\hline & & Ranidae & Part of body & 1 \\
\hline \multirow[t]{3}{*}{ Tropidonophis multiscutellatus } & 2 & Amphibia & & \\
\hline & & Hylidae & Whole body & 1 \\
\hline & & Tadpoles & Whole body & 4 \\
\hline
\end{tabular}

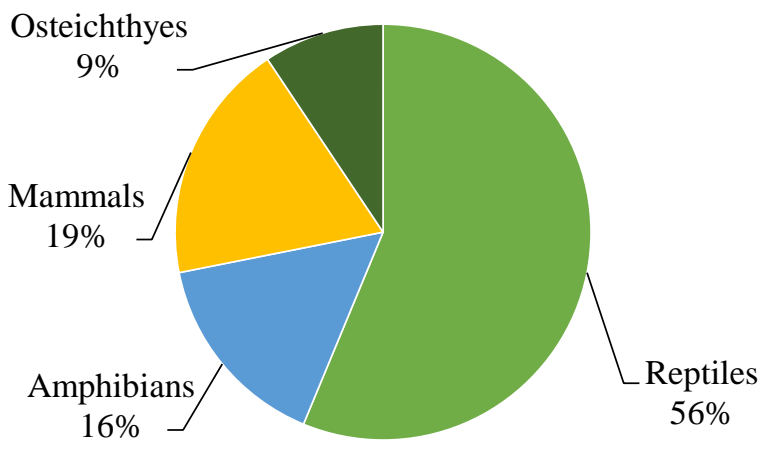

Figure 2. Percentage of four prey classes. The largest class was Reptilia 


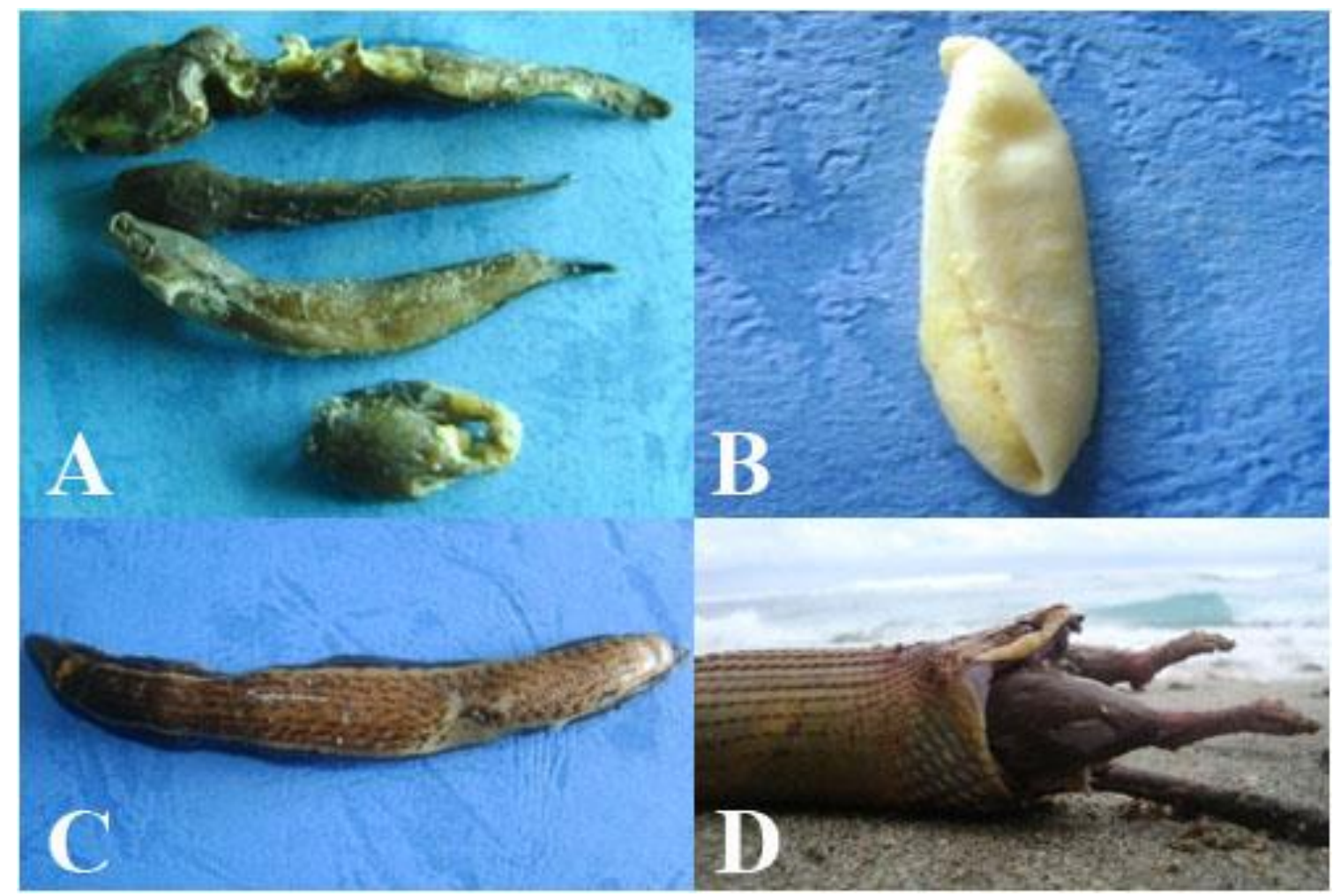

Figure 3. Some view of the prey items ingestion by snakes in Papua. A freshwater fish, Clarias bathrachus, eat by a Tropidonophis mairii from Merauke (A). The shells of reptiles eggs found in the gastrointestinal tract of Stegonotus cuculatus (B). Whole body of Sphenomorphus muelleri was found on the gastrointestinal tract of Micropechis ikaheca from Batanta Island (C). A Pogonomys group was captured and ingestion from head first by Boiga irregularis (D). Photo by Denisa Taran (A, B, C) and Hendrik Burwos (D).

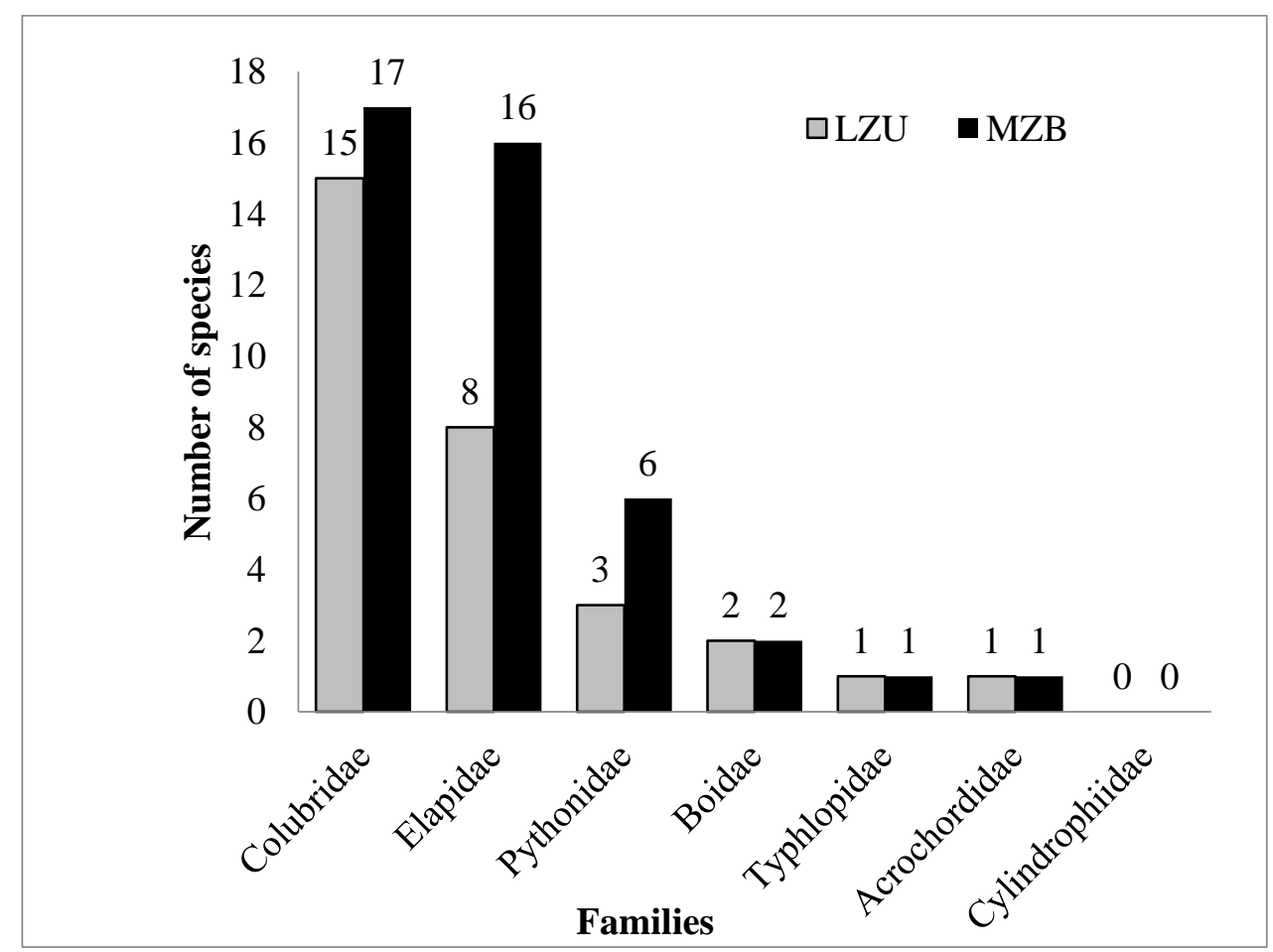

Figure 4. Numbers comparation of specimen collection of snakes at LZU (present study) and MZB (2014). Includes Cylindrophiidae although the species of this family are not stored in LZU and MZB. 


\section{DISSCUSSION}

Snake Species Comparison from Papuan

Biogeographic Region

The list of snake species in LZU (present study) and MZB (2014) is much shorter compared with Allison (2007), which was compiled based on the the literature and specimen collections from around the world. All the collected species of snakes in LZU and MZB (Table 3) reach $35 \%$ and $48 \%$ of the total reported by Allison (2007). The collected specimens of Papuan snakes in LZU today will probably continue to grow in line with the increased research and collection in the future.

Table 3. Snake species comparison from Papuan biogeographic region

\begin{tabular}{lccc}
\hline \multicolumn{1}{c}{ Taxon } & $\begin{array}{c}\text { LZU } \\
\text { (Present } \\
\text { Study) }\end{array}$ & $\begin{array}{c}\text { Allison } \\
\mathbf{( 2 0 0 7 )}\end{array}$ & $\begin{array}{c}\text { MZB } \\
\mathbf{( 2 0 1 4 )}\end{array}$ \\
\hline Acrochordidae & 1 & 2 & 1 \\
Boidae & 2 & 2 & 2 \\
Colubridae & 15 & 28 & 17 \\
Cylidrophiidae & 0 & 1 & 0 \\
Elapidae & 8 & 34 & 14 \\
Pythonidae & 3 & 6 & 6 \\
Typhlopidae & 1 & 10 & 1 \\
\hline Total of species & 30 & 83 & 41 \\
\hline Total of genera & 17 & 41 & 23 \\
\hline Total of families & 6 & 7 & 6 \\
\hline
\end{tabular}

There is no collection of the Cylindrophiidae, Cylindrophis aruensis, in the MZB and LZU until now. C. aruensis is known to be endemic to the Aru Islands (McDowell, 1975), mostly nocturnal and feed on invertebrates and small vertebrates (Allison, 2007). There were 17 and 15 species of colubrid in MZB and LZU collections respectively (Figure 4). Colubrids occupy a diversity of habitats which quite common even in the surrounding residential areas. They are also most often found by accident within the home or plantation, and even in the attic of the home. Colubrid is the largest group in New Guinea, with 34 species from 11 genera (Allison, 2007). This is higher than Australia which has only 10 species (O'Shea, 1996).

The only introduced species of snake collected in the LZU is a colubrid, Lycodon aulicus (SVL: $42.9 \mathrm{~cm}$ ). This non-venomous snake was found in early 2005 near Sentani Airport at Jayapura by Burhan Tjaturadi, a Papuan senior herpetologist. Until now there is no information about life history and potential threat of the Lycodon to native biotas in their new home, Papua. However, we suspect this species have been unintentionally transported by humans by aircraft. Two specimens of the invasive species have been collected from Sentani (Jayapura), Papua province in early 2005 (Tjaturadi et al., 2007). So far at least four specimens of these colubrid have been found by accident near the residential areas around Sentani Lake (including around Sentani Airport), and Waena (Tjaturadi, personal communication). $L$. aulicus has been found to inhabit other Asian regions such as the Philippines, India, China, Burma and other Asian regions to Sumatra, Java, Sulawesi, including several other small islands in the Sunda region like Wetar, Flores, Timor and Alor (Rooij, 1917; McKay, 2006).

\section{Snake Diets}

All snakes are carnivores, unlike other reptiles that feed on nectar, fruit, and leaves (Donoghue, 2006). Morever, Micropechis ikaheca has been reported as a cannibal (O'Shea, 1994b), as well as to prey on other snakes such as Dendrelaphis sp. All items in the diet of snakes that were found in this study were a body or body parts of animals, including reptile shell which showed that all members of this sub-order in Papua are true carnivores. Eggs were considered as the eggs of reptiles based on the severity, not broken, and the folds as well as the size (Hamilton et al., 2012; Gardner \& Mendelson, 2003). The finding of hair in the digestive tract of Morelia viridis, Bothrochilus albertisii, and B. irregularis indicate that they play a role in population regulation of rat, naturally. This is an important focus regarding the preservation of habitats and snakes, let them live freely in their habitat.

Our data (Table 2) indicated that egg shells were only a prey item of adult Stegonotus spp. However, they also eat small frogs, lizards, snakes, small mammals and possibly invertebrates, but primarily reptile eggs (O'Shea, 1996). The diet significant proportion of Stegonotus cucullatus in north Queensland, Australia, were reptile eggs (Trembath et al., 2009). Snakes in general consume far fewer bird 
eggs compared to reptile eggs (Queiroz \& Rodriguez - Robles 2006). The data collected by Queiroz and Rodriguez-Robles showed 45 species of snakes prey on Squamata eggs and only 16 species prey on bird eggs. Scarcity of snakes that eat bird eggs may be caused by the difficulty swallowing since sometimes the eggs are too hard and large to swallow.

In the wild, Stegonotus is often observed in bushes, under a pile of coconut husk and among litter which also is home to other reptile groups. Although terrestrial in nature, Stegonotus is often spotted in the bush about 1-2 meters above ground level so they can reach bird eggs of that height range. Stegonotus is a group of terrestrial snakes, but sometimes it can become fosorial or arboreal species to find prey (O'Shea, 1996).
Traditional Utilization of snakes by the Papuans and Implication to Conservation

Snakes are feared by humans, and many find them uninteresting. This fact also causes these animals far away from research place. As we known, all snakes are definitely the reptiles that always evoke positive and negative responses. Snakes have been present in folklore, mythology, religious, medicine, and used also as the pet trade (Funk, 2006), which probably has contributed to or evoked negative responses to people in all over the world.

In Papua, snakes have traditonally been associated with evil and sin. Consequently, most Papuans are still afraid with all snakes or any thing appearing like a snake. Spontaneous reactions usually occur when they see a snake and

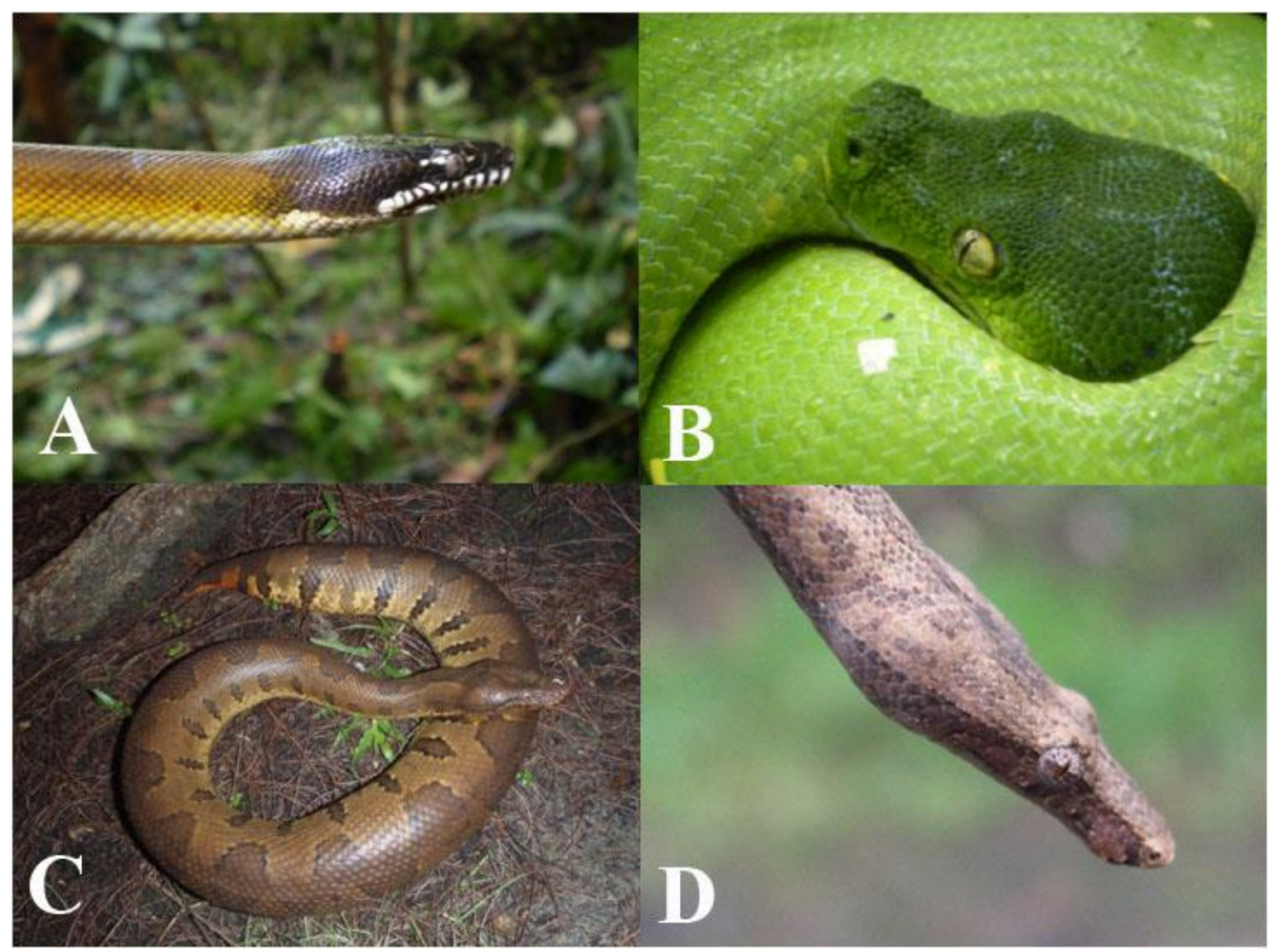

Figure 5. Python and Boa from Papua, a potential exploitation. (A) White-Lipped Python, Bothrochilus albertisii, (B). The only species protected species of Papuan snake under Indonesia Government Regulation No. P.20 2018, Green Tree Python, Morelia viridis from Foja Mt. Mamberamo basin. (C). New Guinea Ground Boa, Candoia aspera from Kuala Kencana, Timika, (D) Pasific Ground and Tree Boas, Candoia carinata from Haya, Mamberamo. Photo by Keliopas Krey. 
without thinking about whether it's venomous or not, people do not hesitate to kill them. Based on the our interviews with Papuan local people, snakes are always at the top of their list of the most feared animals in Papua until now. The local community and even parents often remind each other not to enter and destroy the forest because there are "big and dangerous" snakes. It's funny but we understand this fact as a wisdom as well as benefits for forests conservation in Papua.

Although feared, there is some interesting information about the traditional utilization of snakes by the Papuans. In Papua New Guinea, snakes are used for food, fun, traditional medicine, and also for financial gain (O'Shea, 1996). Some of the indigenous people in Papua eat B. albertisii and Morelia viridis, also used the body parts of snakes for traditional medicine. For example, indiginous people from Arfak Manokwari extracted M. ikaheca to the oil and than use it as a liniment to treat a swelling muscle (Krey obs.). The people in a number of place in vogelkop region catch some species of snakes directly from the wild and sell to people who order for traders. Sometime they sleep in the woods to hunt some snakes such as Bothrochilus albertisii, Candoia aspera, Candoia carinata, and Morelia viridis (Figure 5).

\section{ACKNOWLEDGEMENTS}

Without the support and contribution of various parties, the snake research in Papua might never exist. We are also very grateful to people who may not be included here. Snake specimens studied in this research basically from a variety of collectors and surveys in Papua. We would like thank to Burhan Tjaturadi, Stephen Richard, Neville Kemp, and David Price, and all those who have contributed to the snake specimens at LZU. Special thanks to Laboratory of Herpetology, MZB who have allowed us to use the specimen data of all snakes from Papua.

\section{REFERENCES}

Allen, G. 2000. Marine Fishes of South-East Asia. Periplus Edition, Ltd; Singapure.

Allison, A. 2007. Herpetofauna of Papua. In: Marshall AJ, Beehler BM, editor. The Ecology Indonesia Series Vol. VI. The
Ecology of Papua. Part One. Singapore: Periplus editions.

Beehler, B.M. 2007. Introduction to Papua. In: Marshall AJ, Beehler $\mathrm{BM}$, editor. The Ecology Indonesia Series Vol. VI. The Ecology of Papua. Part One. Singapore: Periplus editions.

Brown, W.C. 1991. Lizards of the Genus Emoia (Scincidae) with observations on their Evolution and Biogeography. The California Academy of Scinces and The Cristensen Research Institut. San Fransisco.

Donoghue, S. 2006. Nutrition. In: Mader DR. Reptile Medicine and Surgery (Second edition). Canada: Saunders Elsevier.

Funk, R.S. 2006. Snakes. In: Mader DR. Reptile Medicine and Surgery (Second edition). Canada: Saunders Elsevier.

Gardner, S.A. \& Mendelson III, J.R. 2003. Diet of the Leaf-Nosed Snakes, Phyllorhynchus (Squamata: Colubridae): Squamate-egg specialists. The Southwestern Naturalist 48(4):550-556.

Hamilton, B.T., Hart, R. \& Sites, J.R.J.W. 2012. Feeding Ecology of the Milksnake (Lampropeltis triangulum, Colubridae) in the Western United States. Journal of Herpetology, Vol. 46, No. 4, 515-522, 2012.

Knight, A.T., Cowling, R.M., Rouget, M., Balmford, A., Lombard, A.T. \& Campbell, B.M. 2008. Knowing but not doing: selecting priority conservation areas and the research-implementation gap. Conserv. Biol. 22, 610-617

Kimura, S. \& Matsuura, K. 2003. Fishes of Bitung Northern Tip of Sulawesi; Indonesia. Ocean Research Institute, The University of Tokyo; Tokyo.

Krey K., O’Shea M., Farajallah A., Setiadi D., Suryobroto B. 2015. Micropechis ikaheka (Elapidae) in Papua, Indonesia: A Study of Diet and Cannibalism. Herpetology Notes, volume 8: 323-328

Muzeum Zoology Bogorienze (MZB). 2014. Catalogue MZB Ophidia. Unpublish.

McDowell, S.B. 1975. A Catalogue of the Snakes of New Guinea and the Solomons, 
with special reference to those in the Bernice P. Bishop Museum. Part II. Aniliodea and Pythoninae. Journal of Herpetology 9 (1): 1-79.

McKay, J.L. 2006. Reptil dan Amphibi di Bali. Krieger Publishing Company.

Menzies, J.I. 1975. Handbook of Common New Guinea Frog. Wau Ecology Institute; PNG.

Menzies, J.I. \& Dennis, E. 1979. Handbook of New Guinea Rodents. Wau Ecology Institute; Papua New Guinea.

O'Shea M. 1994a. Micropechis ikaheka (Smalleyed or Ikaheka snake). Ophiophagy. Herp $\operatorname{Rev} 25(2): 70$.

O'Shea M. 1994b. Micropechis ikaheka (Smalleyed or Ikaheka snake). Cannibalism. Herp Rev 25(2):70-71.

O'Shea, M. 1996. A Guide to the Snakes of Papua New Guinea. Singapure: Beaumont Publishing Pte Ltd, 9 Joo Koon Circle.

Queiroz, A. \& Rodríguez-Robles, J.A. 2006. Historical Contingency and Animal Diets: The Origins of Egg Eating in Snakes. The American Naturalist vol. 167, no. 5.

Rooij, N.D. 1917. The Reptiles of the Indo-
Australian Archipelago. Vol-2, Ophidia. Leiden: E.J. Brill Ltd.

Shine R, Keogh JS. 1996. Food habits and reproductive biology of the endemic Melanesian Elapids: are tropical snakes really different?. J Herp 30(2):238-247.

Taylor, B. \& O'Shea, M. 2004. The Great Big Book of Snakes \& Reptiles. London: Anness Publishing Ltd Hermes House.

Tjaturadi, B., Richards, S. \& Krey, K. 2007. Exotic Herpetofauna: A New Threat to New Guinea's Biodiversity?. In: Marshall AJ, Beehler BM, editor. The Ecology Indonesia Series Vol. VI. The Ecology of Papua. Part One. Singapore: Periplus editions.

Trembath, D.F., Fearn, S. \& Undheim, E.A.B. 2009. Natural history of the slaty grey snake (Stegonotus cucullatus) (Serpentes: Colubridae) from tropical north Queensland, Australia. Australian Journal of Zoo

Whitten T, Soeriaatmadja RE, Afiff SA. 1999. Ekologi Jawa dan Bali. Jakarta (ID): Prenhallindo. 